\title{
PHYTOCHEMICAL CONSTITUENTS AND PHARMACOLOGICAL ACTIVITIES OF Kigelia africana AND Mansoa alliacea - A COMPREHENSIVE REVIEW
}

\author{
SOWMYALAKSHMI VENKATARAMAN ${ }^{1 *}$, GUNDA SRILAKSHMI
}

${ }^{1}$ Department of Pharmaceutical Chemistry and Analysis, School of Pharmaceutical Sciences, Vels Institute of Science, Technology and Advanced Studies (VISTAS), Pallavaram, Chennai, Tamil Nadu, India. ${ }^{2}$ Research Scholar, Department of Pharmaceutical Chemistry and Analysis, School of Pharmaceutical Sciences, Vels Institute of Science, Technology and Advanced Studies (VISTAS), Pallavaram, Chennai, Tamil Nadu, India. Email: sowmyamahesh30@gmail.com

Received: 10 October 2018, Revised and Accepted: 11 December 2018

\section{ABSTRACT}

Context: The focus of the present review is to compile the different phytochemical constituents and pharmacological activities of bignoniaceous plants, namely Kigelia africana and Mansoa alliacea.

Objective: Medicinal plants are routinely used in clinical practice for the treatment of various diseases of human beings over thousands of years across the world. In rural areas of the developing countries, they are still used in practice due to the easy availability of the medication. The main objective of this work is to explore the phytochemical studies and biological activities of plants belonging to Bignoniaceae family.

Methods: The present study also discusses about the different phytochemical constituents of $K$. africana and $M$. alliacea that were isolated and characterized using various analytical methods. Different extracts of these plants were subjected to different in vitro anticancer, analgesic, antimicrobial, and antimalarial activities using earlier reported methods were also discussed.

Results: K. africana is commonly referred to as sausage or cucumber tree due to its huge sausage or cucumber-like fruit. These plants find application as traditional medicine for treating several ailments such as malignant tumor, ulcer, aging, and malaria among others. It is conjointly used for the treatment of reproductive organ infections, renal ailments, dizziness, epilepsy, sickle cell disease, depression, metabolism disorders, skin grievance, leprosy, impetigo, helminthic infections, athlete's foot, tumors, etc. These plant extracts have also been used as a cosmetic by enhancing the collagen action and thus exhibit antiaging properties.

Conclusion: The present study attempts to provide collective information on various phytochemical constituents and pharmacological actions of $K$. africana and M. alliacea belonging to Bignoniaceae. This review in its present form is believed to help the researchers to provide adequate information about the chemical constituents and biological uses of these plants.

Keywords: Bignoniaceae, Kigelia africana, Mansoa alliacea, Phytochemical studies, Pharmacological studies.

(C) 2018 The Authors. Published by Innovare Academic Sciences Pvt Ltd. This is an open access article under the CC BY license (http://creativecommons. org/licenses/by/4. 0/) DOI: http://dx.doi.org/10.22159/ajpcr.2018.v11s4.31703

\section{INTRODUCTION}

Nature has been the supply of several healthful agents within the type of the isolated compound from natural resources for more than thousands of years [1]. Around $80 \%$ of the population across the world depends only on indigenous medicines to protect themselves from various diseases. The family Bignoniaceae is characterized by the woody stem, opposite, compound leaves, and zygomorphic flowers and has been covered in some major floristic projects [2]. The family is comprised about 112 genera and 725 species which are usually seen in tropical and subtropical regions of the world. In India, the family is represented by 15 genera and 40 species [3]. Mansoa alliacea is a native plant to South America, exactly from the Amazonian basin and has been collected in Bolivia, Brazil, Caribbean islands, Colombia, and Ecuador.

\section{Brief description}

Kigelia is a genus of flowering plants within the family Bignoniaceae [4] that consists of just one species, that is, Kigelia africana, fruit grows up to 2 feet long and appears like sausage. K. africana is commonly referred as sausage or cucumber tree due to its huge sausage or cucumber-like fruit [5]. These trees grow up to a height of 10-15 m, leaves decussate or ternate, 20-50 cm long, leaflets 5-9, ovate-oblong to elliptic-ovate, acute or mucronate at apex, often oblique at base, entire flowers in very long drooping lax panicles as narrow, pendent racemes; calyx copular, 2 lipped, greenish, glabrous; corolla dark wine red, 5-10 cm long, throat wide; stamens 4; and fruits shortly beaked $25-30 \mathrm{~cm}$ long commonly called as sausage tree, flowering, and fruiting takes place in the month from March to August [6]

M. alliacea is a native plant to South America, exactly from the Amazonian basin and has been collected in Bolivia, Brazil, Caribbean islands, Colombia, and Ecuador [7]. It is an evergreen climbing shrub with semi-woody branches that allow attaching on larger trees, used as growing supports. The plant reaches $3 \mathrm{~m}$ tall and its leaves are bright green, slightly coriaceous, opposite and characterized by two ovate leaflets of about $15 \mathrm{~cm}$ long. Flowers have funnelform corolla up to 6-9 $\mathrm{cm}$ long, with campanulate calyx, 5-8 $\mathrm{mm}$ long [8]. They are violet colored and grow in terminal or auxiliary raceme inflorescences. Fruits are elongate capsules up to $25-35 \mathrm{~cm}$ long which contain transverse-oblong seeds characterized by broad wings. Leaves of $M$. alliacea are characterized by a pungent garlic-like smell when crushed [9]. The aim of this current review is to explore the different phytochemical and pharmacological research work that was carried out so far on the plants of $K$. africana and M. alliacea belonging to the family Bignoniaceae.

\section{Traditional uses}

Several parts of $K$. africana were traditionally used as medicine by rural people in African countries. In Malwi, the seeds were roasted 
and consumed throughout the famine. Baked fruits were fermented to brew and cooked ones yielded a red-colored dye [10]. Many tribals used various parts of these plants for treating a broader range of skin ailments such as flora infections and boils among others. Boiling of the leaves was utilized for the treatment of infectious disease, worm infestation, postpartum hemorrhage, malaria, diabetes, pneumonia, and aching [11]. Zambezi valley women use these leaves for the removal of blemishes. In folk medicine, fruit extracts were used for the ulcer, purgative, and as galactogogue. Shona individuals used various parts of these plants (bark or root) as infusion or powder for the respiratory disorder used as an analgesic for dental problems and for its medulla spinalis pain-relieving property [12]. The unripe fruit was employed as an antihelminthic and for the treatment of hemorrhoids and rheumatism [13]. Bark powder is employed due to the remedy for venereal diseases [14]. M. alliacea has also got several folklore uses and was used by various ethnic people for different diseases. In Brazil, the leaf extract was used traditionally for treating rheumatoid arthritis, dermal infections, and body cleaning purpose [15]. In South America, people used this plant extract traditionally for analgesic, antiarthritic, anti-inflammatory, antipyretic, antirheumatic, colds, constipation, nausea, pneumonia and respiratory disorders, purgative, and vermifuge [16]. However, all of these are only folklore uses, none of these has not been reported scientifically. Thus, the purpose of this review is to help the future researchers to study the biological effects using scientific models and validate the folklore usage of these plants.

\section{Phytochemical studies}

K. africana

From the phytochemical review of $K$. africana was found to have numerous secondary metabolites such as iridoids, flavonoids, and naphthoquinones, pinnatal and isopinnatal were found in root bark extract. 7-hydroxy viteoid-II, 7-hydroxy eucommic acid, 7-hydroxy10-deoxyeucommiol, and 10-deoxyeucommiol along with few iridoids were isolated [17]. Fruit extract was found to have 6-p-coumaroylsucrose along with known phenylpropanoid and phenylethanoid derivatives [18]. From the heartwood, a major constituent known as kigelin was isolated by Govindachari et al. [19]. Stigmasterol and lapachol were separated from the basis extract of $K$. africana plant. Kigelin, $\beta$-sitosterol, 3-dimethyl kigelin, and ferulic acid were separated from the bark, few quinines, and new aromatic monoterpenes were also separated from the basis bark by Joshi et al.[20]. Verminoside and minecoside were the two iridoids isolated from stem bark using butanol as mobile phase.

\section{M. alliacea}

Essential oils were isolated from the leaves of M. alliacea and found to possess chemical groups such as alkyl trisulfide, disulfide, alkyl characid sulfite, 3-vinyl-1,2-dithi-4-ene, and diisoamyl disulfide [21]. The petroleum ether extract of $M$. alliacea leaves was found to have n-alkanes $\mathrm{C}_{25}-\mathrm{C}_{35}$, n-alkanols, 24-ethylcholest-7ene-3 $\beta$-ol, 19-hydroxyhexatriacontan-18-one, 32-hydroxyhexatriacontan-4one, 34-hydroxy-8-methylheptatriacontan-5-one, pentatriacont-1en-17-ol, $\beta$-sitosterol, stigmasterol [22], etc. A methanolic extract obtained from flowers of $M$. alliacea was found to own allicin, $\beta$-amyrin, apigenin, apigenin-7-glucoside, apigenin-7-glucuronide scutellarein7-glucuronide, apigenin-7-glucuronyl glucuronide, apigenin-70-methyl glucuronide, cyaniding-3-rutinoside, ursolic acid, and luteolin [23]. Essential oils obtained from flowers were found to have diallyl disulfide, diallyl tetrasulfide, diallyl trisulfide, and 1-octen3-ol [24]. Benzaldehyde, benzyl thiol, and dibenzyl disulfide are the inflorescences found in flower extract of M. alliacea [25]. 9-Methoxy$\alpha$-lapachone and 4-hydroxy-9-methoxy-laphachone were separated from bark of $M$. alliacea using methylene chloride and methyl alcohol as mobile phases [26]. p-Coumaric acid and resveratrol, and betulinic acid were isolated from the ether extract and binary compound infusion of entire stuff of M. alliacea [27].

\section{Pharmacological studies}

Anticancer activity

Crude chloride extracts of fruits and bark of $K$. africana showed profound cytotoxic action on in vitro cultured melanoma cells; an isopinnatal isolated compound from the bark of $K$. africana extract showed cytotoxic action on melanoma cells, whereas $\beta$-sitosterol was found to be inactive when compared with isopinnatal toward melanoma cells [28]. Considerable in vitro cytotoxicity was found by the iridoid-related compounds - norviburtinal and naphthoquinone, which were isolated from the fruit and bark extracts of K. africana [29]. Lapachol a compound isolated from Kigelia was found to very effective in solar skin disease, carcinoma, and Kaposi sarcoma (an HIV-related skin ailment) [30]. The antitumor activity of Bignoniaceae could be due to its naphthoquinones, and hence, lapachol has been considered a candidate for clinical use. Similarly the alcoholic and dichloromethane extracts of the roots of K. pinnata, another bignoniaceous plant had shown promising anticancer activity against melanoma and renal cell carcinoma (Caki-2 cell line) [31]. Y-sitosterol isolated from the extract of $K$. africana is known to contribute for the cytotoxic action which is compared with lapachol as the reference drug [32]. Seed oil isolated from $K$. africana has shown significant antiproliferative action on human embryonic kidney cells (HEK-293). M. alliacea leaf extract exhibited T3-HA cancer cells at low concentrations and cytotoxic action was found at higher concentrations [33].

\section{Analgesic activity}

Ethanolic extract of the stem bark of $K$. africana was evaluated for carboxylic acid acid-induced wriggly mouse model; it absolutely was conjointly tested in hot plate time interval and anti-inflammatory property in mice and guinea pigs. The probable mechanism could be due to the inhibition of prostaglandins synthesis at the dose of $500 \mathrm{mg} / \mathrm{kg}$ body weight [34]. Supercritical carbon dioxide extracts of Kigelia have shown potent anti-inflammatory action when compared with indomethacin and by inhibition of cyclooxygenase-2 against human neutrophils [35]. M. alliacea root and stem extracts have shown anti-inflammatory activities by inhibiting prostaglandin synthesis [36].

\section{Antimalarial activity}

Four naphthoquinones were isolated from the basis bark of plant and tested against Plasmodium falciparum strains which are sensitive to antimalarial drug (T9-96) and resistant to chloroquine. K1 the toxicity studies were carried out using computer memory unit cells. Lapachol and other components having antimalarial property was extracted from the roots and they have shown notable effect against malaria caused by resistant strains of P. falciparum [37]. The whole plant extract of $M$. alliacea was screened for antiplasmodial activity using dose of $500 \mathrm{mg} /$ $\mathrm{kg}$ body weight and a notable action was observed [38].

\section{Action on central nervous system}

Ethanolic extract of the stem bark of $K$. africana was extracted using ethanol and was shown to be effective for the treatment of giddiness, drowsiness, and sedation. The stimulant activity of the central nervous system was carried out using mice victimization. The muscle coordination activity was studied using sleeping time induced using barbiturates and rotarod test [39]. The study was carried out using caffeine and diazepam at a dose of $400 \mathrm{mg} / \mathrm{kg}$ body weight which showed improved stimulant activities. The extract did not produce any sedative action on animals throughout entire period and they were found to retain their balance on the rotarod activity.

\section{Antimicrobial activity}

Isolated compounds from the $K$. africana from fruits and roots are believed to have antibacterial and antifungal activity. Isolated compounds such as phenylpropanoids, ferulic acid, and $p$-coumaric acid were screened against Staphylococcus aureus, Bacillus sp., eubacterial organisms, Aspergillus niger, Candida sp., and exhibited important antimicrobial action toward these organisms [40]. Steroids and flavonoids were found to be hygroscopic in nature and exhibited 
significant antifungal action [41]. The chemical investigation revealed that iridoids present in the stem bark of $K$. africana had exhibited potent antimicrobial action against Bacillus subtilis, Escherichia coli, and Monilia albicans among others. The highest zone of inhibition was exhibited by alcoholic extracts than acetonitrile and methylene chloride extracts. Among all the organisms, Pseudomonas aeruginosa and S. aureus were inhibited by $K$. africana extracts [42]. M. alliacea leaf extract was tested against some of the fungal strains of Alternaria brassicae, Colletotrichum capsici, Curvularia lunata, Alternaria alternata, Alternaria brassicicola, Alternaria carthami, Fusarium oxysporum, and Fusarium udum and the extracts showed remarkable antifungal activities [43].

\section{Diuretic action}

The diuretic activity (dose 250 and $500 \mathrm{mg} / \mathrm{kg}$ body weight) was tested on male anomaly rats [44]. Notable diuretic action was exhibited by the $K$. africana extracts by increasing the water volume.

\section{Miscellaneous activities}

Molluscicidal activity was tested on adult snail Biomphalaria glabrata using the isolated compound of lapachol and isolapachol from K. africana by Kela et al. [45]. Ethanol extract of Kigelia showed promising inhibitor activity. The antidiabetic action was also screened by Kela et al. [45]. Biocide activity against Hypsipyla grandella and anopheles was screened using leaf extract of M. alliacea. The cholesterollowering effect was reported in dried flower extracts of $M$. alliacea. The decoction made from the leaves of $M$. alliacea was found to be effective against cough, nausea, and constipation [22]. Allicin was the compound isolated from $M$. alliacea and was found to have very good hydroxyl radical scavenging activity and was also found to exhibit antimicrobial action by affecting the RNA synthesis of microorganisms [46].

K. africana fruit extract is also known strengthen the collagen fibers of the breast [47]. Cream which was prepared from the fruit extract was found to be effective against sunspots known as solar keratosis. From the fruit extracts, shampoos were prepared for treating scalp related infections like psoriasis [48]. The cream prepared from fruit extract also helps in the tightening of the skin surrounding the eyes. The fruit pulp is found to be used as nutraceutical and dietary/herbal supplement, especially in skin tightening active agent [49].

\section{CONCLUSION}

The present review discussed about the phytochemical constituents and pharmacological activities of $K$. africana and M. alliacea belonging to the Bignoniaceae family. $K$. africana is an interesting plant that was widely used in indigenous system of medicine and is thus helpful beyond its original geographical range. The research work carried on these plants reveals that further pharmacological investigation is warranted to prove the folklore usage in a scientific method, as $K$. africana is known for iridoids which get accumulated in roots and flowers; hence, there is a need for the isolation and quantification of these chemicals for toxicological evaluations. It also shows that $M$. alliacea have been partially investigated and the findings presented in the current review make way to further explore folklore uses in a more scientific manner

\section{ACKNOWLEDGMENTS}

The authors are thankful to the management of Vels Institute of Science, Technology and Advanced Studies (VISTAS) for providing the necessary library facilities, infrastructure, and equipment for carrying out the research work.

\section{AUTHORS' CONTRIBUTION}

The authors SV and GS had contributed equally toward the collection of literature and preparation of the manuscript.

\section{CONFLICTS OF INTEREST}

The authors declare that they have no conflicts of interest.

\section{REFERENCES}

1. Cragg GM, Newman DJ. Medicinals for the millennia: The historical record. Ann N Y Acad Sci 2001;953:3-25.

2. Otimenyin SO, Uzochukwu DC. Spasmolytic and anti-diarrhea effects of the bark of Erythrina senegalensis and the root of Kigelia africana. Asian J Pharm Clin 2012;3:11-4.

3. Olatunji AG, Atolani O. The comprehensive scientific demystification of Kigelia africana: A review. Nat Prod Rad 2009;8:190-7.

4. Jackson S, Beckett K. Sausage tree Kigelia pinnata: An ethnobotanical and scientific review, herbal gram. Am Bot Counc 2012;94:48-59.

5. Khan SS, Malhotra D. Plantagentic diversity exploration evaluation, conservation: Angiospermic diversity in Bhopal-reassessment with particular reference to endangered species and their conservation. Vol. 232. East: West Press Pvt Ltd.; 2002. p. 234.

6. Mathad P, Shrishail C. Floristic diversity of a famous historical baridshahi fort of boidarin Karnataka. Indian J For 2008;31:577-80.

7. Arana VF. Control de Hipsiphyla grandella Zeller en plantaciones de Cedrela odorata L. (cedro rojo) con Mansoa alliacea (Lam) A. H Gentry (ajo sacha). Conocimiento 2005;8:59-67.

8. Agra MF, Silva KN, Basilo IJ, Franca PF, Barbosa-Filho JM. Survey of medicinal plants used in the region Northeast of Brazil. Rev Bras Famacogn 2008;18:472-508.

9. Ariga T, Seki T. Antithrombotic and anticancer effects of garlic-derived sulfur compounds: A review. Biofactors 2006;26:93-103.

10. Burkil HM. The Useful Plants of Tropical West Africa. $2^{\text {nd }}$ ed. England: Royal Botanical Garden Kew; 1985. p. 254-57.

11. Gill LS. Ethnomedicinal Uses of Plants in Nigeria. Benin City: Uniben Press; 1992. p. 143.

12. Pooley E. The Completed Guide to Trees of Natal, Zululand, and Transkei. Durban: Natal Flora Publications Trust; 1993. p. 22-4.

13. Irvine FR. Woody Plants of GHANA, with Special References to their Uses. London, United Kingdom: Oxford Univesity Press; 1961. p. 736-40.

14. Walt JM, Breyer-Bradwijk MG. The Medicinal and Poisonous Plants of Southern and Eastern Africa. Livingstone: E. \& S. Livingstone; 1962. p. 52 .

15. Lanalice RF, Tavares-Martins AC. Chemical and ethnopharmacology mystical plants in an amazonian community. Rev Fitos 2016;10:220-372.

16. Abril RV, Vasquez TE, Lazo JA, Banguera DV, Guyasamin PD, Vargas $\mathrm{JK}$, et al. The use of medicinal plants by rural populations of Pastaza Province in the Ecuadorian amazon. Acta Amazonica 2016;46:355-66.

17. Gouda YG, Abdel-Baky AM, Mohamed KM, Darwish FM, Kasai R, Yamasaki K, et al. Phenylpropanoid and phenylethanoid derivatives from Kigelia pinnata DC. Fruits. Nat Prod Res 2006;20:935-9.

18. Gouda YG, Gouda YG, Abdel-Baky AM, Mohamed KM, Darwish FM, Kasai R, et al. Iridoids from Kigelia pinnata DCC, fruits. Phytochemistry 2003;63:887-92.

19. Govindachari TR, Patankar SJ, Viswanathan N. Isolation and structure of new dihydroios coumarins from Kigelia pinnata. Phytochemistry 1971;10:1603-6.

20. Joshi KC, Singh P, Taneja S, Cox PK. New terpenoid aldehydes from Kigelia pinnata crystal structure of pinnatal. Tetrahedron 1982;38:2703-8

21. Zoghbi MG, Ramos LS, Maia JG, Miriam L, da Silva ML, Luz AI. Volatile sulfides of the amazonian garlich bush. J Agric Food Chem 1904;32:1009-10.

22. Zoghbi MG, Oliveira J, Skelding GM, Guilhon P. The genus Mansoa (Bignoniaceae): A source of organosulphur compounds. Rev Bras Farmacogn 2009;19:795-804.

23. Zoghbi MD, Andrade EH, Maia JG. Volatile constituents from Adenocalymma alliaceum Miers and Petiveria alliaceae L. Two medicinal herbs of the amazon. Flavour Fragr J 2009;2002:133-5.

24. da Silverira GD, Motta MJ, Muller LS, Lameira O, Athayde ML, Piana $\mathrm{M}$, et al. Determination of phenolic antioxidants in amazonian medicinal plants by HPLC with pulsed amperometric detection. J Liq Chromatogr Relat Technol 2015;3:1-8

25. Gobo LA, Viana C, Lameira OA, de Carvalho LM. A liquid chromatography-atmospheric pressure photoionization tandem mass spectrometric (LC-APPI-MS/MS) method for the determination of triterpenoids in medicinal plant extracts. J Mass Spectrom 2016;51:558-65.

26. Saez AL, Soto JP. Fitoquimica y valor ecologico del olor a ajo en los vegetables. Med Naturista 2010;4:15-23. 
27. Pires FB, Dolwitsch CB, Pra VD, Monego DL, Schneider VM, Loose RF, et al. An overview about the chemical composition and biological activity of medicinal species found in the Brazilian amazon. J Appl Pharm Sci 2016;6:233-8.

28. Jackson SJ, Houghton PJ, Retsas S, Photiou A. In vitro cytotoxicity of norviburtinal and isopinnatal from Kigelia pinnata against cancer cell lines. Planta Med 2000;66:758-61.

29. Inoue K, Inoue H, Chen C. Quinones and related compounds in higher plants, a naphthoquinone and a lignin from the wood of Kigelia pinnata. Phytochemistry 1981;20:2271-6.

30. Hussain H, Krohn K, Ahmad UV, Miana GA, Green IR. Lapachol: An overview. ARKIVOC 2007;2:145-71.

31. Houghton PJ, Photiou A, Uddin S, Shah P, Browning M, Jackson SJ, et al. Activity of extract of Kigelia pinnata against melanoma and renal carcinoma cell lines. Planta Med 1994;60:430-3.

32. Rao MM, Kingston DG. Plant anticancer agents: Isolation and structure elucidation of new cytotoxic quinines from Tabebuia cassinoides. J Nat Prod 1982;45:600-4

33. Towne CM, Dudt JF, Ray DB. Effect of Mansoa alliacea (Bignoniaceae) leaf extract on embryonic and tumorigenic mouse cell line. J Med Plants Res 2015;9:799-805.

34. Owolabi OJ, Omogbai EK. Analgesic and anti-inflammatory activities of the ethanolic stem bark extract of Kigelia africana (Bignoniaceae). Afr J Biotechnol 2007;6:582-5.

35. Forschung N. Use of Mixtures, Which Contain Parts of the Plant Kigelia africana. Hans Knoll Institute for Naturstoff Patent Number DE10200490; 2003.

36. Pires FB, Dolwitsch CB, Pra VD, Monego DL, De Carvalho LM, Viana C, et al. Qualitative and quantitative analysis of the phenolic content of Connarus var angustifolius, Cecropia obtuse, Ceropial palmata and Mansoa alliace based on HPLD-DAD and UHP;LC-ESIMS/MS. Rev Bras Farmacogn 2017;27:426-33.

37. Weiss CR, Moideen SV, Croft SL, Houghton PJ. Activity of extract and isolated naphthoquinones from Kigelia pinnata against Plasmodium falciparum. J Nat Prod 2000;63:1306-9.

38. Ruiz L, Maco M, Cobos M, Gutierrez-Choquevilca AL, Roumy V. Plants used by native amazonian groups from many rivers (Peru) for the treatment of malaria. J Ethnopharmacol 2011;133:917-21.

39. Owolabi OJ, Amaechina FC, Eledan AB. Central nervous system stimulant effect of the ethanolic extract of Kigelia africana. J Med Plants Res 2008;2:20-3.

40. Akunyili DN, Houghton PJ, Raman A. Antimicrobial activities of the stem bark of Kigelia pinnata. J Ethnopharmacol 1991;35:173-7.

41. Binutu OA, Adesogan KE, Okogun JI. Antibacterial and antifungal compounds from Kigelia pinnata. Planta Med 1996;62:352-3.

42. Grace OM, Light ME, Lindsey KI, Mulholland DA, Vanstaden J, Jager AK. Antibacterial activity and isolation of active compounds from the fruit of the traditional African medicinal tree Kigelia africana. S Afr J Bot 2002;68:220-2.

43. Freixa B, Vila R Vargas L, Lozano N, Adzet T, Canigueral S. Screening for antifungal activity of nineteen Latin American plants. Phytother Res 1998; 12:427-30

44. Akah PA. The antidiarrheal activity of Kigelia africana in experimental animals. J Herbs Spices Med Plants 1998;2:31-8.

45. Kela SL, Ogunsusi RA, Ogbogu VC, Nwude N. Screening of some Nigerian plants for molluscicidal activity. Rev Elev Med Vet Pays Trop 1989;42:195-202.

46. Sharma RK. Phytosterols: Wide spectrum antibacterial agents. Bioorg Chem 1993;21:49-60.

47. Dampier C. Cosmetic Compositions with High Viscosity for Female Breast Care Containing Kigelia Extract. Patent Number: US 2002/0176874; 2002

48. Isamu M. Skin Care Preparation. Patent Number: JP2003137763; 2003.

49. Martins N, Petropoulos S, Ferreira IC. Chemical composition and bioactive compounds of garlic (Allium sativum L), as affected by pre and post-harvest conditions-a review. Food Chem 2016;211:41-50. 